\title{
Kondisi Sosial Ekonomi Masyarakat Dusun Ngentak Srandakan Bantul Pasca Pengembangan Objek Wisata Pantai Baru
}

\author{
Kurnia Dewi Arini dan V. Indah Sri Pinasti \\ Pendidikan Sosiologi, Fakultas Ilmu Sosial, Universitas Negeri Yogyakarta \\ Email : kdewi.1998@gmail.com
}

\begin{abstract}
Abstrak
Penelitian ini bertujuan untuk mengetahui kondisi sosial ekonomi masyarakat sebelum dan sesudah pengembangan wisata Pantai Baru, bentuk partisipasi masyarakat Dusun Ngentak, dan dampak pengembangan wisata Pantai Baru terhadap kondisi sosial ekonomi masyarakat Dusun Ngentak. Penelitian ini menggunakan metode kualitatif deskriptif dengan teknik pemilihan informan menggunakan teknik purposive sampling sebanyak 13 orang. Teknik pengumpulan data dilakukan dengan observasi, wawancara dan dokumentasi. Validitas data menggunakan teknik triangulasi sumber. Hasil penelitian menunjukan bahwa pengembangan objek wisata Pantai Baru memberikan perubahan pada kehidupan masyarakat. Pengembangan wisata Pantai Baru berhasil karena adanya peran partisipasi masyarakat. Masyarakat berpartisipasi secara langsung dalam pengembangan yang berupa partisipasi dalam bentuk uang, tenaga, gotong royong, keterampilan, dan pikiran. Dampak positif adanya yaitu peralihan mata pencaharian dari pertanian ke sektor wisata, pemerataan tingkat pendidikan, modernitas perempuan, memperluas wawasan, menambah lapangan pekerjaan, menyerap banyak tenaga kerja, peningkatan pendapatan, peningkatan kesejahteraan, peningkatan harga jual hasil bumi dan penerimaan devisa Pemerintah Kabupatan Bantul. Dampak negatifnya yaitu permasalahan sampah, penyimpangan sosial yang dilakukan wisatawan dan sifat konsumtif.
\end{abstract}

Kata kunci: Pariwisata, Kondisi Sosial Ekonomi, Pengembangan Wisata Pantai Baru

\begin{abstract}
This study aims to discover the socio-economic conditions before and after the development of Pantai Baru tourism, Ngentak Village society's participation forms, and the development impact of Pantai Baru tourism on the socio-economic conditions of Ngentak Village society. This study used a descriptive qualitative method using 13 purposives sampling techniques to select the informants. Data was collected with observation, interview and documentation. Source triangulation method was used for data validation. The results show that the development of Pantai Baru tourism changes villager's life. The development of Pantai Baru tourism was successful because of villager's participation. The villagers participate directly to develop Pantai Baru tourism in the form of money, energy, mutual cooperation, skills, and ideas. The positive impacts are the transition of livelihoods from agriculture to the tourism sector, equal distribution of education levels, women's modernity, broadening horizons, increasing employments, absorbing a lot of workforces, increasing income, increasing welfares, increasing the selling price of agricultural products and receiving foreign exchange for Bantul Regency Government. The negative impacts are waste problems, deviations by tourists and consumptive nature.
\end{abstract}

Keywords: Tourism, Socio-Economic Conditions, Pantai Baru Tourism Development 


\section{Pendahuluan}

Pengembangan sektor pariwisata saat ini sangat strategis. Banyak masyarakat yang tengah gencar mengembangkan potensi pariwisata di wilayah masing-masing. Dengan berkembangnya potensi pariwisata tersebut menjadi salah satu sektor yang dapat menguntungkan bagi masyarakat. Oleh karena itu, banyak daerah yang berkeinginan untuk mengembangkan potensi wisata yang ada di wilayahnya. Kabupaten Bantul menjadi salah satu daerah yang tengah mengembangkan potensi pariwisatanya. $\mathrm{Di}$ wilayah Kabupaten Bantul, terdapat potensi pariwisata yang bisa menjadi daya tarik. Oleh masyarakat beberapa potensi tersebut dikembangkan menjadi objek pariwisata yang mempunyai nilai nominal dan memberikan dampak bagi masyarakat sekitar, salah satunya objek wisata pantai. Objek wisata pantai di Kabupaten Bantul yang sudah di kelola antara lain, Pantai Parangtritis, Pantai Depok, Pantai Samas, Pantai Pandansari, Pantai Goa Cemara, Pantai Kuwaru, Pantai Pandansimo, Pantai Parangendog, Pantai Baros dan Pantai Baru (Nofendi, 2019). Dari banyaknya wisata pantai yang tengah dikembangkan di Kabupaten Bantul, terdapat salah satu objek wisata yang sedang fenomenal yaitu Wisata Pantai Baru.

Wisata Pantai Baru merupakan salah satu destinasi yang sedang digandrungi oleh wisatawan. Kawasan Objek Wisata Pantai Baru yang terletak di Dusun Ngentak, Poncosari, Srandakan, Bantul. Pada awalnya dikelola karena adanya keresahan warga terkait kondisi sosial Pantai Pandansimo. Menurut warga Dusun Ngentak, objek wisata Pantai Pandansimo yang sudah didirikan sejak tahun 1980 dalam pengelolaannya tidak berjalan dengan baik. Hal inilah yang menjadi salah satu alasan warga Dusun Ngentak untuk mulai menata dan membangun wisata Pantai Baru. Dengan inisiatif ini, masyarakat bertekad untuk membangun wisata Pantai Baru dari dana swadaya masyarakat setempat. Pada bulan Juni Tahun 2010, Pantai Pandansimo Baru atau Pantai Baru dibuka oleh masyarakat. Konsep yang dikembangkan oleh Pokdarwis adalah wisata kuliner pantai untuk keluarga. Dengan perubahan nama dan perubahan konsep, Pantai Baru kini menjadi objek wisata yang lebih menarik.

Wisata Pantai Baru menjadi tujuan kedua wisata alam setelah wisata Pantai Parangtritis (Novriani, 2016). Hal ini terjadi karena objek wisata Pantai Baru mempunyai kharakteristik yang berbeda dari wisata pantai di sekitar. Keelokan objek wisata Pantai Baru yang menarik wisatawan mempengaruhi banyaknya pengunjung yang datang. Berdasarkan data statistik di Dinas Pariwisata dapat dilihat jumlah pengunjung dari tahun ke tahun mengalami kenaikan (Dinas 
Pariwisata, 2018). Data pengunjung Pantai Baru tahun 2015-2019 sejumlah 523.836, 553.226, 661.730, 771.348, 614.046 pengunjung.

Bertambahnya jumlah pengunjung di kawasan wisata Pantai Baru dapat memberikan dampak karena, berkembangnya sektor pariwisata di suatu daerah menurut UU No. 10 Tahun 2009 akan menarik sektor lain untuk berkembang. Sehingga terjadi perubahan kegiatan perekonomian dan kondisi sosial masyarakat sesuai dengan tujuan pengembangan pariwisata (Kurniawan, 2015).

Menurut (Pitana \& Gayatri, 2005), Pariwisata merupakan suatu kegiatan yang secara langsung menyentuh dan melibatkan masyarakat, sehingga membawa berbagai dampak terhadap masyarakat setempat. Namun, pengembangan pariwisata juga tidak terlepas dari peran partisipasi masyarakat sekitar dalam pengelolaanya. Keberhasilan pengembangan pariwisata tidak hanya melihat dari peningkatan jumlah pengunjung tetapi bagaimana struktur perekonomian dan kehidupan sosial masyarakat disekitar objek wisata Pantai Baru. Peneliti mengambil judul penelitian ini karena beberapa alasan seperti ingin mengetahui kondisi sosial ekonomi masyarakat, partisipasi yang diberikan masyarakat dan dampak yang ditimbulkan dari adanya pengembangan objek wisata Pantai Baru terhadap kondisi sosial ekonomi masyarakat Dusun Ngentak.

\section{Metode}

Penelitian ini menggunakan metode penelitian kualitatif dengan pendekatan deskriptif. Metode penelitian kualitatif digunakan sesuai dengan tujuan penelitian yaitu mengamati masyarakat untuk mengetahui secara detail bagaimana kondisi sosial ekonomi masyarakat Dusun Ngentak Poncosari Srandakan Bantul pasca pengembangan wisata Pantai Baru.

Penelitian ini dilakukan pada bulan Desember 2019 sampai dengan bulan Februari 2020 di Dusun Ngentak, Desa Poncosari, Kecamatan Srandakan, Kabupaten Bantul dan di kawasan objek wisata Pantai Baru.

Subjek dalam penelitian ini adalah warga masyarakat Dusun Ngentak Poncosari Srandakan Bantul baik pengelola, pekerja di objek wisata Pantai Baru maupun tokoh masyarakat, Kepala Desa Poncosari, dan Dinas Pariwisata Kabupaten Bantul. Untuk memperoleh subjek penelitian menggunakan teknik purposive sampling, dengan subjek penelitian sebanyak 13 informan.

Data yang digunakan dalam penelitian ini adalah data primer dan data sekunder. Data primer diperoleh langsung dari subjek penelitian dengan cara wawancara dan pengamatan di lapangan. 
Data primer dalam penelitian ini dari pengelola objek wisata Pantai Baru, masyarakat Dusun Ngentak baik yang bekerja di lokasi objek wisata maupun tokoh masyarakat, Kepala Desa Poncosari dan Dinas Pariwisata Kabupaten Bantul. Sedangkan data sekunder dalam penelitian adalah studi kepustakaan, dokumentasi, jurnal, catatan lapangan, dan data dari pokdarwis maupun Dinas Pariwisata.

Penelitian ini menggunakan validitas data dengan teknik triangulasi sumber sebagai teknik keabsahan data. Triangulasi sumber yang dilakukan dalam penelitian ini dengan melakukan uji silang pada catatan wawancara dan observasi untuk memastikan tidak ada informasi yang bertentangan diantara keduanya. Penelitian ini menggunakan teknik analisis data dari Mills dan Huberman (Sugiyono, 2014). Analisis data dalam penelitian ini mengunakan 4 tahap proses yaitu pengumpulan data, reduksi data, penyajian data, dan penarikan kesimpulan.

\section{Hasil dan Pembahasan}

Dusun Ngentak merupakan daerah administratif objek Wisata Pantai Baru. Objek wisata pantai baru menjadi salah satu wisata pantai yang sedang naik daun di kawasan pantai selatan. Objek wisata Pantai Baru didirikan atas inisiatif dan kerja keras dari warga Dusun Ngentak. Masyarakat Dusun Ngentak secara swadaya menata dan mengembangkan kawasan tersebut menjadi suatu objek wisata. Awalnya masyarakat Dusun Ngentak mengelola wisata Pantai Pandansimo, wisata ini jaya sekitar tahun 1970-1980 namun dikarenakan terjadi kesalahan dalam pengelolaan sehingga muncul bisnis prostitusi dan juga adanya kerusakan alam akibat abrasi yang menjadikan objek wisata Pantai Pandansimo menjadi sepi pengunjung. Kemudian masyarakat Dusun Ngentak mempunyai inisiatif untuk mengembangan wisata baru di sebelah timur Pantai Pandansimo yang berjarak kurang lebih 500 meter yang diberi nama wisata Pantai Baru.

Penataan objek wisata Pantai Baru oleh masyarakat Dusun Ngentak di mulai pada Bulan Maret 2010. Kemudian dilanjutkan dengan pembentukan Kelompok Sadar Wisata. Pada bulan Juni 2010 objek wisata Pantai Baru mulai dibuka untuk umum dan mulai menerima wisatawan.

Objek wisata Pantai Baru memiliki daya tarik tersendiri karena rimbunan pohon cemara udang dan kincir angin sebagai Pembangkit Listrik Tenaga Hibrid (PLTH). Kondisi sarana dan prasarana di lokasi Pantai Baru yang sudah memadahi menjadi salah satu faktor daya tarik wisatawan. Terlebih didukung aksesibilitas menuju Pantai Baru yang sudah layak dengan jalan menuju objek wisata sudah di 
aspal dan dapat dilalui oleh semua jenis kendaraan. Sarana dan prasarana sebagai peranan penting dalam pariwisata. Saranan dan prasarana di Pantai Baru sudah memadahi seperti adanya sarana ibadah berupa masjid dan beberapa kios menyediakan tempat untuk ibadah. Sarana toilet umum yang bisa dikatakan layak digunakan, prasarana listrik yang mengunakan jasa PLN dan PLTH tenaga hybrid, tempat parkir yang luas dan layak. Objek wisata Pantai Baru menawarkan daya tarik berupa wisata alam, wisata kuliner dan karya wisata. Selain itu di objek wisata ini juga terdapat atraksi ATV dan Ritual Kebudayaan seperti upacara labuhan dan sedekah laut.

Dengan adanya pengembangan objek wisata Pantai Baru menyebabkan adanya perubahan dalam masyarakat Dusun Ngentak khususnya dalam bidang sosial ekonomi.

\section{Kondisi Sosial Ekonomi Masyarakat Sebelum dan Sesudah} Pengembangan Wisata Pantai Baru

a. Kondisi Sosial Ekonomi Masyarakat Dusun Ngentak Sebelum Adanya Pengembangan Wisata Pantai Baru

$$
\text { Sebelum adanya }
$$
pengembangan objek wisata Pantai Baru, masyarakat Dusun Ngentak dalam pemenuhan kebutuhan sehari-hari sebagian besar bekerja sebagai buruh tani, nelayan, dan pekerja serabutan untuk memenuhi kebutuhan pokok. Sebagian besar masyarakat Dusun Ngentak bekerja sebagai buruh tani dan nelayan yang bekerja dengan mengandalkan musim dan cuaca, hal ini tentunya berpengaruh dalam pendapatan.

Berdasarkan data sebelum adanya pengembangan wisata Pantai Baru kondisi perekonomian masyarakat bisa dikatakan masih rendah. Bahkan untuk ibu rumah tangga hanya mengandalkan penghasilan dari suami. Karena sebagian besar dari ibu rumah tangga hanya sebagai ibu rumah tangga biasa tanpa ada ketrampilan kecuali memasak. Disisi lain kondisi sosial masyarakat masih tertutup akan perubahan dan dalam hal pola pikir yang menyebabkan masih rendahnya tingkat pendidikan anak di Dusun Ngentak, karena kondisi ekonomi dan tidak ada dorongan dari keluarga.

b. Kondisi Sosial Ekonomi Masyarakat Dusun Ngentak Sesudah Adanya Pengembangan Wisata Pantai Baru

Kondisi sosial ekonomi masyarakat Dusun Ngentak setelah adanya pengembangan wisata Pantai Baru terjadi kenaikan dalam taraf kehidupan masyarakat kearah 
yang lebih baik. Adanya

dalam memenuhi kebutuhan pengembangan objek wisata Pantai Baru mempengaruhi kondisi sosial ekonomi masyarakat Dusun Ngentak. Kondisi sosial ekonomi masyarakat pasca pengembangan wisata Pantai Baru terjadi peningkatan dalam hal perekonomian dan pemikiran masyarakat yang lebih terbuka akan hal baru. Terjadi peningkatan perekonomian karena saat ini banyak ibu-ibu yang bekerja di lokasi objek wisata.

Terjadinya peningkatan perekonomian karena saat ini mata pencaharian masyarakat menjadi lebih bervariasi seperti pedagang, penjaga ATV, penjaga parkir, penjaga retribusi, penjaga kamar mandi, dan tenaga kebersihan kebersihan di objek wisata. Perubahan mata pencaharian sebagai akibat dari terbukanya lapangan pekerjaan dan dapat menyerap banyak tenaga kerja baik dari dalam maupun luar Dusun Ngentak. Pengembangan objek wisata Pantai Baru membantu masyarakat dalam hal keuangan sehingga kehidupan masyarakat Dusun Ngentak menjadi lebih sejahtera. Masyarakat Dusun Ngentak bisa dikatakan sejahtera karena masyarakat lebih mudah sehari-hari dengan lebih layak.

Peningkatan kesejahteran masyarakat mempengaruhi dalam hal pendidikan anak dan pola pikir dalam masyarakat. Pengembangan objek wisata Pantai Baru tidak mempengaruhi dalam hal hubungan solidaritas dan kekeluargaan dalam masyarakat Dusun Ngentak.

\section{Bentuk Partisipasi Masyarakat}

Partisipasi masyarakat Dusun Ngentak Poncosari Srandakan Bantul dalam pengembangan wisata Pantai Baru dilakukan sejak awal pengembangan wisata. Pengembangan wisata Pantai Baru oleh masyarakat Dusun Ngentak merupakan usaha dari masyarakat untuk masyarakat Dusun Ngentak dengan tujuan menaikan pendapatan dan kesejahteraan masyarakat. Sehingga masyarakat sangat aktif dan berperan besar dalam pengembangan objek wisata Pantai Baru. Masyarakat sejak awal pengelolaan yakin bahwa objek wisata Pantai Baru dapat meningkatkan taraf hidup masyarakat menjadi lebih baik. Pengembangan wisata Pantai Baru diharapkan menjadi aset masa depan untuk anak cucu mereka, hal ini yang menjadi motivasi masyakat untuk terus berjuang mengembangkan wisata Pantai Baru dengan sebaik mungkin agar wisatawan terus mengalami peningkatan. 
Partisipasi masyarakat Dusun Ngentak dapat dikategorikan sebagai bentuk partisipasi langsung. Karena pengembangan objek wisata Pantai Baru berasal dari inisiatif masyarakat. Masyarakat tidak hanya sekedar objek pembangun, tetapi dalam proses pengembangan masyarakat ikut mengusulkan dan menentukan segala sesuatu rencana yang akan dilaksanakan. Berdasarkan data di lapangan ditemukan bentuk-bentuk partisipasi yang diberikan masyarakat Dusun Ngentak dalam pengembangan objek wisata Pantai Baru meliputi.

a. Partisipasi Dalam Bentuk Uang

Pengembangan objek wisata Pantai Baru yang dimulai dari pembukaan lahan, penataan hingga akhirnya dikembangkan menjadi objek wisata. Masyarakat Dusun Ngentak berpartisipasi dalam bentuk uang untuk kegiatan kerja bakti pembukaan lahan dan sebagai awal biaya pendaftaran. Masyakat yang ikut berjualan wajib membayar biaya pendaftaran yang dikategorikan menjadi 3 (tiga) kriteria. Berdasarkan hasil di lapangan pada awal pengembangan biaya yang dibutuhkan berasal dari swadaya masyarakat Dusun Ngentak, dan dari hasil pinjaman ke suatu bank.

b. Partisipasi Dalam Bentuk Tenaga

$$
\text { Partisipasi tenaga yang }
$$

diberikan masyarakat Dusun Ngentak dapat dilihat dari keikutsertaan masyarakat dalam gotong-royong membuka lahan hingga pembangunan sarana dan prasarana wisata. Kondisi kawasan objek wisata Pantai Baru berupa alas yang penuh dengan tumbuhan duri dan pandan yang mengharuskan masyarakat Dusun Ngentak membersihkan kawasan tersebut sebelum membuka menjadi objek wisata Pantai Baru. Selain membersihkan, masyarakat Dusun Ngentak juga menata kawasan wisata Pantai Baru agar tercipta suasana pariwisata yang nyaman bagi wisatawan yang datang.

Keikutsertaan masyarakat dalam pengawasan lingkungan seperti pengamanan agar wisatawan merasa nyaman. Salah satu bentuk pengawasan yang dilakukan masyarakat Dusun Ngentak adalah membuat aturan agar pedagang asongan tidak berjualan di area pinggir pantai dan kawasan cemara. Hal ini bertujuan untuk menertibkan pedagang asongan demi terciptanya keteraturan dan memberi kenyamanan bagi wisatawan. Karena area wisata Pantai Baru memang diutamakan untuk kesejahteraan warga Dusun Ngentak sehingga pedagang asongan dan masyarakat di luar Dusun Ngentak bisa berjualan 
tetapi di lokasi yang sudah ditentukan oleh pengelola yaitu di Pasar yang letaknya di sebelah selatan lokasi parkiran wisata Pantai Baru, terkecuali untuk masyarakat di luar dusun yang bekerja sebagai tenaga bantu untuk rumah makan maupun depot ikan.

Bentuk partipasi yang diberikan masyarakat dalam bentuk gotongroyong dilakukan dari awal pembukaan lahan hingga wisata sudah berkembang masyarakat selalu gotong-royong dalam proses pelaksanaannya. Seperti perbaikan infrastruktur dan kebersihan lingkungan dilakukan secara gotongroyong oleh masyakarakat, pekerja, dan pengelola wisata Pantai Baru. Selain gotong royong bentuk partisipasi tenaga yang hingga saat ini dilakukan yaitu melakukan pengawasan agar wisatawan merasa nyaman dan aman di lokasi objek wisata Pantai Baru.

c. Partisipasi Dalam Bentuk Ketrampilan

Partisipasi keterampilan yang diberikan oleh masyarakat Dusun Ngentak dalam pengembangan objek wisata Pantai Baru antara lain berupa sosialisasi oleh pokgiat kepada masyarakat Dusun Ngentak secara luas terkait pengembangan objek wisata Pantai Baru. Selain sosialisasi yang diberikan dari pokgiat, masyarakat juga ikut berpartisipasi dalam sosialisasi dan pelatihan yang diberikan oleh Dinas Pariwisata Kabupaten Bantul. Sehingga partisipasi masyarakat dalam pengembangan dilakukan sebelum objek wisata dikembangkan hingga objek wisata Pantai Baru berkembang.

d. Partisipasi Dalam Bentuk Pikiran Partisipasi yang dilakukan masyarakat Dusun Ngentak dalam proses pengembangan tidak hanya meliputi uang, tenaga, keterampilan, namun juga dalam bentuk pikiran yang mereka sumbangkan berupa pikiran, ide maupun usulan sehingga objek wisata dapat dikembangkan dan dikelola sampai saat ini, yang memberikan begitu banyak manfaat untuk masyarakat Dusun Ngentak dan sekitarnya.

Dalam pengembangan Pantai Baru masyarakat juga dilibatkan dalam hal pengambilan keputusan terkait aturan dan kesepakatan yang harus dilaksanakan, salah satunya kesepakatan dalam hal harga baik itu harga sewa ATV, Kamar Mandi, Kolam renang, maupun harga jual kuliner dan makanan lainya yang ada di objek wisata Pantai Baru.

Bentuk partisipasi lainya yaitu dengan mengadakan pertemuan antara pengelola dengan semua masyarakat yang bekerja pada objek wisata Pantai Baru. Pertemuan 
tersebut berupa arisan yang diselingi dengan evaluasi terkait objek wisata Pantai Baru. Sehingga masyarakat dapat mengutarakan keluhan, saran, dan ide mereka demi terwujudnya objek wisata yang semakain baik.

\section{Dampak Pengembangan Wisata}

\section{Pantai Baru}

Dampak pengembangan wisata Pantai Baru memberikan perubahan dalam kehidupan masyarakat Dusun Ngentak, Poncosari, Srandakan, Bantul. Perubahan yang terjadi dalam masyarakat Dusun Ngentak merupakan konsekuensi dari adanya pengembangan wisata Pantai Baru. Masyarakat Dusun Ngentak yang awal mulanya merupakan masyarakat yang bekerja di sektor pertanian dan nelayan kini mulai beralih menuju masyarakat pada sektor pariwisata.

Perubahan yang terjadi pada masyarakat Dusun Ngentak melalui beberapa tahapan perubahan sosial. Perubahan pada masyarakat Dusun Ngentak berdasarkan teori yang dikemukan oleh Rogers dalam (Lindawati, 2013), tahap perubahan sosial terjadi pada masyarakat Dusun Ngentak sebagai akibat adanya pengembangan objek wisata Pantai Baru sebagai berikut:

a. Invention

Proses perubahan pada masyarakat Dusun Ngentak terjadi karena adanya ide dan gagasan dari masyarakat Dusun Ngentak untuk mengembangkan wisata Pantai Baru, yang awalnya kawasan lahan terbengkalai. Ide dan gagasan pengembangan objek wisata Pantai Baru menjadi suatu ide baru yang diciptakan oleh sekelompok individu yang ada di masyarakat kemudian ide dan gagasan baru tersebut dikembangkan ke dalam masyarakat Dusun Ngentak.

b. Diffusion

$$
\text { Merupakan }
$$

proses pengomunikasian ide gagasan kepada anggota sistem sosial. Ide gagasan untuk pengembangan wisata Pantai Baru muncul dari sekelompok individu dalam masyarakat Dusun Ngentak, kemudian disampaikan kepada pokgiat. Proses penyampaian ide dan gagasan kepada masyarakat Dusun Ngentak dilakukan melalui sosialisasi dan rembug warga terkait adanya gagasan pengembangan objek wisata Pantai Baru.

c. Consequence

Merupakan proses perubahan dalam sistem masyarakat sebagai hasil dari adopsi atau penolakan terhadap ide-ide baru. Setelah adanya sosialisasi dan rembug warga maka dapat diketahui respon masyarakat Dusun Ngentak terkait ide pengembangan objek wisata Pantai Baru. Respon masyarakat yang diberikan yaitu respon positif dengan 
menerima (adopsi) adanya pengembangan wisata yang dapat dilihat dari banyaknya masyarakat yang ikut berpartisipasi dalam usaha pengembangan.

Berdasarkan tahapan perubahan sosial yang terjadi pada masyarakat Dusun Ngentak dapat dianalisis penyebab terjadinya perubahan sosial karena adanya penemuan baru. Penemuan baru berupa ide gagasan dari masyarakat terkait pengembangan objek wisata Pantai Baru. Ide dan gagasan terkait pengembangan objek wisata Pantai Baru yang muncul dari inisiatif masyarakat Dusun Ngentak. Ide dan gagasan tersebut merupakan pemikiran dari sekelompok individu dalam masyarakat Dusun Ngentak. Sehingga, perubahan sosial yang terjadi pada masyarakat Dusun Ngentak dapat dikategorikan ke dalam perubahan sosial immanent changer di mana perubahan ini berasal dari sistem sosial itu sendiri dengan sedikit atau tanpa inisiatif dari luar. Selain terjadinya perubahan dalam masyarakat, pengembangan wisata akan memberikan pengaruh terhadap masyarakat sekitar objek wisata. Dampak yang ditimbulkan merupakan konsekuensi yang harus diterima masyarakat antara lain:

a. Dampak Pengembangan Wisata Terhadap Kehidupan Sosial

1) Dampak Positif Terhadap Kehidupan Sosial
Menurut (Pitana \& Diarta, 2009) pengembangan objek wisata memberikan manfaat dampak positif dalam kehidupan sosial diantaranya pengen objek wisata Pantai Baru terhadap kehidupan sosial masyarakat Dusun Ngentak:

a) Transisi Dan Tranformasi Tenaga Kerja Dari Sektor Pertanian Ke Sektor Jasa Termasuk Pariwisata Pengembangan objek wisata Pantai Baru secara kasat mata memberikan banyak peluang lapangan pekerjaan untuk masyarakat. Banyak masyarakat yang sebelum adanya pengembangan objek wisata Pantai Baru bekerja pada sektor pertanian khusunya buruh tani yang hasilnya kurang menentu dan beberapa masyarakat yang pekerjaanya masih serabutan bahkan belum mendapatkan pekerjaan. Setelah adanya objek wisata banyak dari mereka yang beralih ke dalam sektor pariwisata. Peralihan mata pencaharian dikarenakan hasil yang diperoleh dan yang dirasakan masyarakat jauh lebih banyak 
di sektor pariwisata sehingga berpengaruh pada tingkat pendapatan masyarakat.

b) Pemerataan

Tingkat

Pendidikan

Bertambahnya tingkat kesejahteraan dalam masyarakat memberikan pengaruh terhadap kehidupan sosial masyarakat. Salah satunya dalam bidang pendidikan. Peningkatan pendidikan atau persamaan kesempatan yang diperoleh anak-anak di Dusun Ngentak mengalami kenaikan karena masyarakat telah mengalami perubahan dalam pola pikir sehingga ada dorongan untuk menyekolahkan anak ke jenjang yang lebih tinggi. Disisi lain karena adanya dorongan dari keluarga karena telah terjadi kenaikan taraf hidup lebih sejahtera. Saat ini orang tua sudah memiliki pekerjaan yang tetap dan kondisi keuangan juga mengalami kenaikan.

c) Modernisasi Keluarga Berupa Status Baru Perempuan Perkembangan wisata Pantai Baru mempengaruhi status perempuan dalam keluarga. Sebelum adanya pengembangan wisata Pantai Baru masyarakat Dusun Ngentak sebagian besar untuk perempuan seperti ibu rumah tangga tidak mempunyai pemasukan sama sekali dan hanya mengurusi rumah tangga.

Dengan pengembangan objek wisata Pantai Baru banyak perempuan yang terserap. Hampir sebagian besar pekerjaan di bagian warung makanan dikelola perempuan, yang mana dalam satu warung membutuhkan 3-8 tenaga perempuan. Padahal pada objek wisata Pantai Baru kurang lebih terdapat 90 warung makan di objek wisata.

Sehingga, perempuan yang sebelum adanya objek wisata sudah bekerja bisa menambah penghasilan dan bagi perempuan yang hanya di rumah bisa mendapatkan pekerjaan pokok dan dapat membantu perekonomian keluarga.

d) Memperluas Wawasan dan Cara Pandang Masyarakat

Pangaruh dari pengembangan objek wisata Pantai Baru yang paling terlihat adalah mendatangkan banyak wisatawan dari luar. Hal tersebut menyebabkan terjadinya interaksi 
antara masyarakat dengan wisatawan. Melalui interaksi tersebut masyarakat dapat berbagi informasi dan berbagai ilmu sehingga menambah wawasan dan pengetahuan masyarakat.

Keberadaan wisatawan yang datang di kawasan objek wisata Pantai Baru mempengaruhi attitude masyarakat Dusun Ngentak yang mengalami perubahan karena berubahnya cara pandang masyarakat dengan wisatawan. Dengan berkembangnya objek wisata Pantai Baru masyarakat bisa menambah pengetahuan dari pelatihan-pelatihan yang diberikan oleh Dinas terkait. Sehingga masyarakat dapat menerapkan ilmu yang sudah didapat kepada orang lain.

2) Dampak Negatif Terhadap Kehidupan Sosial

a) Masalah Sampah

Permasalahan sampah
terjadi karena banyaknya
wisatawan yang berkunjung dan
membawa makanan dari luar dan
meninggalkan sampah begitu
saja. Sampah yang ditinggalkan
lambat laun akan menganggu
kenyamanan wisatawan lainya.
Selain menganggu juga

menimbulkan bau yang tidak sedap. Permasalahan sampah yang dikeluhkan di objek wisata Pantai Baru tidak hanya dari pengunjung saja tetapi juga sampah dari warung makan. Sampah dari limbah warung makan berupa kotoran ikan, dan kelapa muda yang sampai saat ini menjadi permasalahan yang ada dilokasi Pantai Baru.

b) Penyimpangan

Perilaku menyimpang yang dilakukan oleh wisatawan di objek wisata Pantai Baru berupa minum-minuman alkohol yang mana perilaku tersebut bisa menganggu kenyamanan dan keamanan bagi wisatawan lain. Sudah banyak himbauan dari pihak pengelola namun hal tersebut masih belum efektif di karenakan masih ada beberapa masyarakat khususnya pedagang yang membiarkan hal tersebut dan memaklumi karena faktor ekonomi dimana masyarakat khususnya pedagang apabila mau menegur khawatir akan kehilangan pelanggan mereka. Sehingga hal ini selalu menjadi kekhawatiran masyarakat dan pengelola karena secara tidak langsung akan memberikan pengaruh yang buruk bagi 
masyarakat juga citra buruk di objek wisata Pantai Baru.

b. Dampak Pengembangan wisata terhadap kehidupan Ekonomi

1) Dampak Positif Terhadap Kehidupan Sosial

a) Terciptanya Lapangan Pekerjaan

Pengembangan wisata

Pantai Baru menciptakan lapangan pekerjaan untuk masyarakat. Sehingga kesempatan kerja bagi masyarakat Dusun Ngentak semakin bertambah luas karena menyediakan lapangan usaha baru untuk masyarakat. Masyarakat tidak lagi hanya bekerja pada sektor pertanian saja tetapi bisa berkembang ke sektor wisata.

b) Meningkatnya Penghasilan Masyarakat

Pengembangan objek
wisata Pantai Baru selain
memberikan lapangan pekerjaan
untuk masyarakat Dusun Ngentak
dan sekitarnya, juga memberikan
manfaat pada meningkatnya
penghasilan masyarakat.
Terutama untuk masyarakat yang
awalnya belum memiliki
pekerjaan tetap atau hanya
sebagai pekerja serabutan dan
ibu rumah tangga dengan

pengembangan objek Wisata Pantai Baru sangat membantu. Terlebih pengunjung objek wisata Pantai Baru dari tahun ke tahun mengalami peningkatan. Peningkatan penghasilan masyarakat dari pekerjaan sebelumnya kisaran $40 \%-60 \%$.

c) Meningkatnya Kesejahteraan Masyarakat

Pengembangan objek wisata Pantai Baru memberikan dampak positif tingkat kesejahteraan masyarakat. Masyarakat Dusun Ngentak bisa dikatakan meningkat dalam kesejahteraan karena telah memenuhi indikator dari Badan Pusat Statistik (BPS).

Peningkatan kesejahteraan masyarakat dikarenakan bertambahnya pendapatan masyarakat. Masyarakat yang sebelumnya sudah bekerja bisa mempunyai pekerjaan tambahan, masyarakat yang belum bekerja dapat memperoleh pekerjaan, maka terjadi kenaikan pendapatan dalam masyarakat dan masyarakat lebih mudah dalam pemenuhan kebutuhan pokok maupun kebutuhan lainya.

d) Peningkatan Penjualan Hasil Pertanian

Pengembangan wisata 
Pantai Baru mengakibatkan terjadi peningkatan penjualan maupun hasil penjualan pada sektor pertanian masyarakat. Hal tersebut terjadi karena terdapat pasar hasil bumi yang biasanya diserbu wisatawan sebagai salah satu buah tangan selain souvenir dan ikan hasil nelayan. Dengan adanya pasar hasil bumi di kawasan objek wisata Pantai Baru memberikan manfaat bagi para petani untuk menjual hasil buminya bisa secara langsung ke konsumen tanpa harus melewati orang lain seperti sebelum adanya objek wisata Pantai Baru dan pasar hasil bumi.

e) Bertambahnya Pendapatan Devisa Pemerintah Kabupaten Bantul

Pengembangan objek menghadirkan banyak wisatawan. Wisatawan yang datang setiap tahunya mengalami penambahan yang berdampak pada bertambahnya hasil retribusi, sehingga bertambah pula devisa Pemerintah Kabupaten Bantul. Berdasarkan data dari pokdarwis data pengunjung setiap tahunnya mengalami kenaikan. Data jumlah pengunjung dari tahun 2011 sampai dengan data tahun 2019 sebagai berikut.

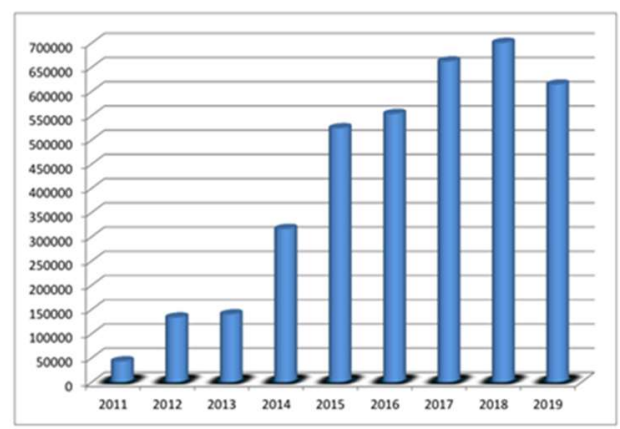

Gambar 1.1 Data Kunjungan Wisata Pantai BaruTahun 2011-September 2019

Jika dilihat, pengunjung objek wisata Pantai Baru dari tahun ke tahun mengalami kenaikan, jika dijumlah dari tahun 2015-2019 sebanyak 3.124.186 pengunjung.

Dengan bertambahnya pengunjung mempengaruhi bertambahnya penerimaan devisa pemerintah kabupaten khususnya Pemerintah Daerah Kabupaten Bantul sebagai dampak positif dalam bidang perekonomian.

2) Dampak Negatif Terhadap Kehidupan Ekonomi

a) Konsumtif

$$
\text { Perilaku }
$$

konsumtif merupakan perilaku yang boros, karena mengonsumsi barang atau jasa secara berlebihan. Perilaku konsumtif yang terjadi di Dusun Ngentak karena kondisi masyarakat yang mulai sejahtera dengan adanya kenaikan pendapatan. Perilaku konsumtif 
yang dirasakan masyarakat

Dusun Ngentak pasca pengembangan objek wisata

Pantai Baru. Karena masyarakat saat ini lebih mudah dalam memperoleh pendapatan.

Teori Struktural Fungsional (Ritzer \& Goodman, 2008) yang dikemukakan oleh Talcott Persons mengembangkan apa yang dikenal dengan imperatifimperatif fungsional agar sebuah sistem bertahan. Imperativeimperatif tersebut adalah Adaptasi, Pencapaian Tujuan, Integrasi, dan Latensi, yang disebut dengan skema tindakan AGIL merupakan singakatan dari Adaption, Goal Attainment, Integration, dan Latency.

\section{Adaption (Adaptasi),} merupakan penyesuaian proses adaptasi yang dilakukan oleh masyarakat Dusun Ngentak dengan suatu keadaan yang baru. Dimana dulunya lahan pertanian tadah hujan kemudian sekarang berubah menjadi kawasan wisata yang mengharuskan masyarakat menyesuaikan tingkah laku yang bukan lagi sebagai petani namun sebagai pengelola wisata yang harus selalu berhadapan dengan pengunjung dan harus selalu ramah. Maka diperlukan penyesuaian dengan lingkungan untuk pemenuhan kebutuhan.

Goal

Attainment

(Pencapaian Tujuan), yaitu sebuah sistem harus mendefinisikan dan mencapai tujuan utama. Berdirinya wisata Pantai Baru bertujuan untuk meningkatkan kesejahteraan masyarakat Dusun Ngentak. Hal tersebut sudah diwujudkan dengan pengembangan wisata Pantai Baru yang dapat meningkatkan perekonomian masyarakat dan pendapatan yang menjadikan masyarakat Dusun Ngentak menjadi lebih sejahtera karena banyak tenaga kerja yang diserap ke dalam objek wisata tersebut.

Integration (Integrasi), merupakan sebuah sistem yang harus mampu mengatur dan menjaga hubungan bagianbagian yang menjadi komponennya, dalam hal ini masyarakat mengatur dan menjaga hubungan baik antar pihak pengelola dan dinas terkait. Hubungan masyarakat dalam mewujudkan tujuan adaptasi yang dilakukan dirasa tidak sia-sia karena dengan adanya wisata Pantai Baru masyarakat dapat mengubah pola pemikiran dan 
perekonomian menjadi lebih maju.

Latency (Latensi), merupakan suatu sistem harus mampu berfungsi melengkapi, memelihara pola, dan memperbaiki motivasi individu dan pola-pola budaya yang menciptakan dan mempertahankan motivasi tersebut. Dengan adanya wisata Pantai Baru, masyarakat berusaha melengkapi sarana prasarana yang belum ada yang dilakukan oleh warga masyarakat dengan tetap memelihara polapola kehidupan yang sama agar masyarakat rukun dan tenteram. Disisi lain masyarakat dapat melihat peluang pekerjaan di wisata Pantai Baru dan selalu berusaha menjaga wisata agar dapat dijadikan untuk aset masa depan anak cucu.

\section{Simpulan}

Berdasarkan pembahasan yang telah diuraikan, penulis dapat memberikan kesimpulan terkait pengembangan objek Wisata Pantai Baru, kondisi sosial ekonomi sebelum dan sesudah, peran partisipasi masyarakat Dusun Ngentak, dan kondisi sosial ekonomi masyarakat Dusun Ngentak Pasca pengembangan wisata Pantai Baru. Pengembangan objek wisata
Pantai Baru tidak lepas dari kontribusi masyarakat Dusun Ngentak dan kelompok sadar wisata. Pengembangan objek wisata Pantai baru juga memberikan dampak terhadap perubahan kondisi sosial ekonomi masyarakat. Perubahan yang terjadi di masyarakat Dusun Ngentak bersifat permanen, karena masyarakat terus akan menerima dampak perubahan selagi objek wisata Pantai Baru masih berkembang. Dilihat dari pengelolaannya yang berjalan dengan baik dan terstruktur sesuai dengan anjuran dan arahan dari Dinas Pariwisata objek wisata Pantai Baru bisa terus mempertahankan kualitas. Kondisi sosial ekonomi masyarakat sebelum dan sesudah pengembangan objek wisata Pantai Baru mengalami perubahan. Sebelum adanya pengembangan kondisi ekonomi masyarakat tergolong masih rendah. Kondisi sosial masyarakat masih kuat akan kekeluargaan tetapi dalam pola pikir dan pendidikan anak rendah. Setelah adanya pengembangan kondisi ekonomi meningkat taraf hidup masyarakat menjadi lebih baik. Untuk kondisi sosial terjadi perubahan dalam pola pikir dan pemerataan pendidikan. Pengembangan objek wisata Pantai Baru tidak lepas adanya peran partisipasi masyarakat secara langsung, yang ikut andil dalam pengembangan dari awal hingga saat ini. Bentuk partisipasi masyarakat yang diberikan berupa: partisipasi dalam bentuk 
uang, partisipasi dalam bentuk tenaga berupa gotong royong, partisipasi keterampilan, dan partisipasi dalam bentuk pikiran yang berupa ide, gagasan dan saran. Keberadaan objek wisata Pantai Baru memberikan dampak positif dan negatif. Dampak dari segi sosial pengembangan wisata Pantai Baru memberikan dampak positif berupa, peralihan mata pencaharian dari pertanian ke sektor wisata, pemerataan tingkat pendidikan, kesempatan yang sama untuk perempuan ikut andil dalam sektor wisata, modernisasi keluarga berupa status baru perempuan, dan memperluas wawasan dan cara pandang masyarakat. Kemudian untuk dampak negatifnya yaitu permasalahan lingkungan berupa masalah sampah dan penyimpangan yang dilakukan oleh wisatawan berupa meminum minuman keras. Dampak dari ekonomi sebagai akibat pengembangan wisata Pantai baru dari segi positinya yaitu, menambah lapangan pekerjaan, menyerap tenaga kerja, meningkatkan pendapatan masyarakat, masyarakat semakin sejahtera, peningkatan penjualan hasil pertanian, dan peningkatan pendapatan devisa. Kemudian dampak negatifnya munculnya sifat konsumtif dari masyarakat Dusun Ngentak.

\section{Ucapan Terima Kasih}

Terima kasih kepada semua pihak yang mendukung penulisan artikel ini dan kepada tim redaksi Jurnal Dimensia Pendidikan Sosiologi UNY yang telah menerbitkan karya ini.

\section{Daftar Pustaka}

Lindawati, Y. I. (2013). Dampak pengembangan wisata Pantai Goa Cemara terhadap kehidupan sosial dan ekonomi masyarakat Dusun Patihan Gadingsari Kec. Sanden Kab. Bantul. Yogyakarta: Skripsi Universitas Negeri Yogyakarta.

Dinas Pariwisata. (2018). Statistik Kepariwisataan 2017. Yogyakarta: Visiting Jogja.

Kurniawan, W. (2015). Dampak Sosial Ekonomi Pembangunan Pariwisata Umbul Sidomukti Kecamatan Bandungan Kabupaten Semarang. Semarang: Skripsi Universitas Negeri Semarang.

Nofendi. (2019, November 24). 48 Tempat Wisata Di Bantul Terbaru Yang Wajib Dikunjungi. Retrieved from eksotisjogja.com:

https://eksotisjogja.com/tempatwisata-di-bantul-yogyakarta/6/

Novriani, E. D. (2016). Dampak Kegiatan Pariwisata di Pantai Baru Kabupaten Bantul Terhadap Pendapatan Masyarakat Sekitar. Yogyakarta: Skripsi Universitas Gajah Mada.

Pitana, P. G., \& Diarta, I. K. (2009). Pengantar IImu Pariwisata. Yogyakarta: ANDI.

Ritzer, G., \& Goodman, D. J. (2008). Teori Sosiologi. Yogyakarta: Kreasi Wacana.

Sugiyono. (2014). Metode Penelitian Pendidikan (Pendekatan kuantitatif, kualitatif, dan R\&D). Bandung: ALFABETA. 